\title{
SOCIO-DEMOGRAPHIC PREDICTORS OF JOB SATISFACTION AMONG SPORTS COUNCIL ADMINISTRATORS IN SOUTHERN NIGERIA
}

\author{
J. A. Adelakuni, \\ T. T. Orunaboka, \\ G. A. Deemua \\ Department of Human Kinetics and Health Education, \\ Faculty of Education, \\ University of Port Harcourt, \\ Nigeria
}

\begin{abstract}
:
This study investigated socio-demographic predictors of job satisfaction among sports council administrators in southern Nigeria. The study was aimed at achieving two objectives. Two research questions were raised and answered while two null hypotheses were formulated and tested. The study employed a cross-sectional survey design. The population of the study comprised 3000 sports council administrators in southern Nigeria. Stratified random sampling technique was adopted to get the sample size of 450 sport administrators from the South-South, South-East and South-West sub-regions in Southern Nigeria. An instrument tagged 'Questionnaire on Socio-Demographic Predictors of Job Satisfaction' (QSDPJS) was used for data collection. A reliability coefficient of 0.86 was obtained for the instrument. Percentages, Mean score $\left.{ }^{(\bar{x}}\right)$, standard deviation and multiple regression were the statistical tools used for data analysis. Some of the findings showed that sixty per cent $(60 \%)$ of sports administrators in southern Nigeria are not satisfied with their job. Also, socio-demographic variables of age, gender, educational qualification, length of service could jointly predict job satisfaction of state sports council administrators. Based on these findings, it was concluded that the observed poor performance of most southern states in various national sports competitions in Nigeria can be attributed to low extent of job satisfaction among sports council administrators. It was therefore recommended that state governments in the southern sub-regions of Nigeria should make prompt payment of sports council workers at the end of the month a priority and sport administrators' salary, welfare packages and other emoluments should be enhanced.
\end{abstract}

Keywords: socio-demographic, job, satisfaction, sports, council, administrators

i Correspondence: email akasm29@gmail.com 


\section{Background to the Study}

A sport organisation may have the best of facilities and equipment, the best of technologies or even the best of policies, but if there are no well-motivated workers who are satisfied with their job to utilise and maintain those facilities, equipment and technologies as well as satisfied workers to implement those well-formulated policies, nothing meaningful could be achieved by such sports organisation (Deemua, 2020; Orunaboka \& Ogulu, 2015). Thus, sport councils in various states in Nigeria are managed by different people to produce the desired result (Deemua, \& Alaubi, 2018; Orunaboka, 1998). Various personnel at various cadres and departments work together to bring about positive results of producing top athletes at state level, design programmes of activities and to manage sports equipment and facilities of the state (Adelakun, 2021). Therefore, the success of any sports organisation, whether public or private, profit-making or nonprofit making organisation is contingent on the productivity, which is sometimes a byproduct of job satisfaction (Orunaboka, et al, 2015).

Job satisfaction is the constructive, positive, encouraging or progressive inner feeling that influences a worker's mind-set towards his work. It is a personal, congenial emotional state that results from someone's job, which in an ideal situation encourages productivity. Martins and Proenca (2012) stated that job satisfaction is usually treated as an assemblage of feelings or emotional responses associated with the job situation. It can be simply described as how workers feel about different aspects of their work. Laurie (2010) opined that job satisfaction is an attitude, an internal state, which could be associated with a personal feeling of achievement, either quantitative or qualitative.

Similarly, Oshagbemi (as cited in Adelakun, 2021) summarised the concept of job satisfaction from the gamut of reviewed literature and described job satisfaction as an emotional response to a job that results from the similarity between the actual outcomes and those that are desired. Job satisfaction is determined by how far and how well a job situation meets the expectation of the worker. There are things that a worker expects from his job. These things could be his expectations while working or in anticipation of life after his working career, but which could be an offshoot of his present work. For instance, a worker may expect regular promotion and higher pay over a certain period in his organisation or he may expect a certain policy that will guarantee a comfortable life after retirement (Adelakun, 2021). If these expectations are met or even surpassed by the organisation, there is the likelihood that such a worker would be satisfied with his job. Job satisfaction, therefore, is the positive inner feeling that a worker gains from the totality or aspects of his job, which influences his disposition constructively towards his job when his hopes, aspirations, targets, wishes, desires or expectations are met or surpassed by his organisation (Adelakun, 2021). When the gap between promise and reality is bridged or totally closed, there is every tendency that the worker will be satisfied with his job.

The level of job satisfaction of sports administrators in a sport council could be affected by a wide array of variables such as social-demographic, administrative, 
environmental, economic, psychological, organisational or cultural factors. Sociodemographic variables are the general characteristics of a population whose features include gender, age, and educational qualification, length of service, marital status, and location and so on. Socio-demographic factors play a significant role in job satisfaction (Deemua, et al., 2018). Socio-demographic factors could be personal attributes or workrelated attributes or combination of both. In this study, personal attributes include age, sex and educational qualification while work-related socio-demographics include length of service and rank. Thus, this study focused on socio-demographic predictors of job satisfaction among sports council administrators in southern Nigeria.

\section{Statement of the Problem}

There is a dearth of domain-specific literature and empirical studies on the impact of socio-demographic on job satisfaction in sport management in Nigeria. The limited amount of research on job satisfaction in the sports industry has created a huge gap in the field of sport management. Researchers in the field of sports management often rely on empirical studies from other disciplines, and these cannot totally cover facets of job satisfaction in sport industries, because it is a non-traditional industry with different modes of operations.

Moreover, new athletes are difficult to be sighted in any major athletic competitions in Nigeria nowadays. Old athletes are always recycled. Reasons are not clear if this is as a result of either athletes' personal attributes, rank, length of service or combination of these variables. What therefore impelled the researcher is, how sociodemographic variables can predict job satisfaction among sports council administrators in southern Nigeria. Simply put, to what extent can socio-demographic variables predict job satisfaction among sports council administrators in southern Nigeria?

\subsection{Aim and Objectives of the Study}

This study was aimed at assessing socio-demographic predictors of job satisfaction among sports council administrators in southern Nigeria. Specifically, the objectives were to:

1) investigate the extent of job satisfaction of sport administrators in the sports council in southern Nigeria; and,

2) determine the extent to which socio-demographic variables of gender, age, educational qualification, length of service and rank independently predict job satisfaction of sport administrators in the sports councils in southern Nigeria.

\subsection{Research Questions}

1) To what extent are sport administrators in the sport council in southern Nigeria satisfied with their job? 
2) To what extent do the socio-demographic variables of gender, age, educational qualification, length of service and rank independently predict job satisfaction of sport administrators in the sports council in southern Nigeria?

\subsection{Hypothesis}

A null hypothesis was tested at 0.05 level of significance:

- Socio-demographic variables of age, gender, educational qualification, length of service and rank, independently will not significantly predict job satisfaction of sport administrators in sport council in southern Nigeria.

\section{Conceptual Framework}

The concepts of this study is situated on sport administration and the impact of sociodemographic variables on job satisfaction of sports council administrators in sport council as diagrammatically indicated below.

Figure 1: Conceptual Framework

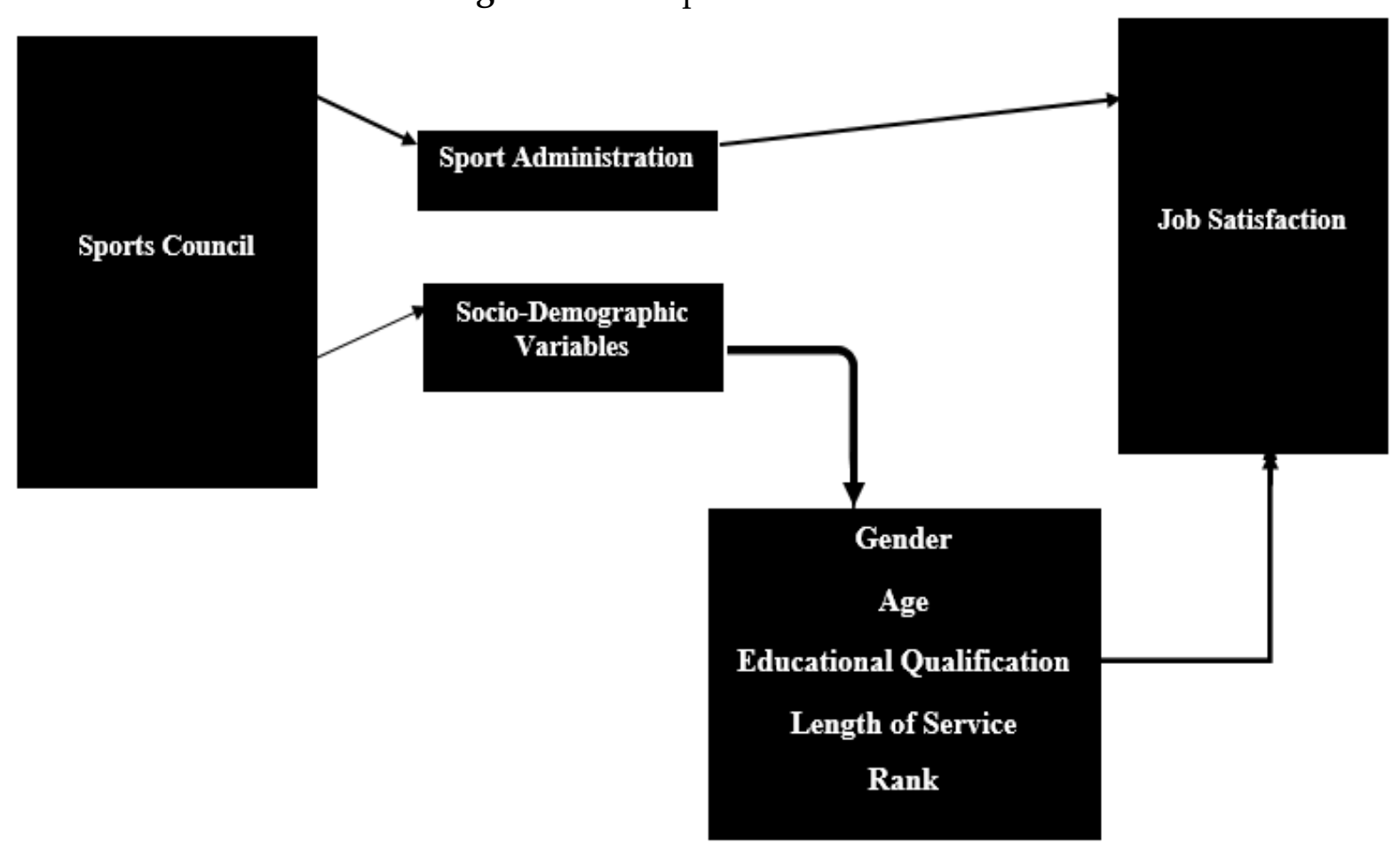

Source: Researchers' conceptualization (2021).

\subsection{Conceptual Review}

\subsubsection{Level of Sports Administration}

In Nigeria, the administration of sports has different levels and different aims. Fasan (as cited in Adelakun, 2021) listed the levels of sports administration as follows: 


\section{a. International Level}

This involves administration of sports at global, regional or continental level as found in the sport governing bodies like International Olympic Committee (IOC), Federation of International Football Association (FIFA). It also involves organization of sports at continental level like the Nations Cup, confederation of African football (CAF), champions' league, and at sub regional level like West African Football Union (WAFU) cup (Elendu, 2013).

\section{b. National Level}

This is the administration of sport within a country. In Nigeria, bodies like The Nigeria Olympic Committee, National Sports Commission including individual Sport Federations are responsible for administering sports in Nigeria (Elendu, 2013).

\section{c. State Level}

This has to do with administration of State Sports Councils and Zonal offices. Sport at state level is mostly for discovery and training of raw talents and preparing the talents for National competitions (Deemua, et al., 2018).

\section{d. Local Government Level}

This is the administration of sport at the grass root level.

Institutional Sport: This is the administration of sports in schools. It could be Nigerian University Games Association (NUGA), Nigeria Polytechnic Games Association (NIPOGA), Nigeria College of Education Games Association (NICEGA) or secondary schools game or even primary schools sports festival, non-governmental/ private organisations (Ekpo, 2016). This has to do with management of sport at club level. Sometimes it could be companies like the Union Bank hockey club, First bank club, Ikoyi Golf club and so on. Administration of sports at the state level is coordinated by sport administrators in state sports council which is usually located at the state capital. A typical sports council according to Adelakun (2021) must have the following unit:
a) Training and Research Division;
b) General administration and Finance Division;
c) Sport organizing and coaching division;
d) Sports Medical Centre;
e) Stadium Management Division;
f) Public Relations Division; and,
g) Legal Division.

\subsection{Evolution of Sports Council in Nigeria}

Before the independence in 1960, efforts were made by political leaders to explore ways that could make sport occupy its rightful place in the scheme of things in Nigeria. Adesanya (as cited in Adelakun, 2021) explained that a bill to establish the Western Region Sports Council was signed into law on December 9, 1959 by the then last colonial 
Governor of the Region, Sir John Dalzell Rankine. The principal objective of the council as laid down in the instruments establishing it according to Adelakun (2021) was to encourage participation and improvements of the standards of performance in sports and also to encourage and assist amateur participation in sports. Amateur' means any person who:

(a) Participate in sport solely for pleasure and for the physical, mental or social benefits he derives there from and to whom participation in sports is nothing more than recreation without material gain of any kind, direct or indirect: and

(b) Is organized by the council either individually, or as a member of a class or section of the public to be an amateur in that sport for the purpose of this law.

The establishment of the Western Region Sports Council was followed by the establishment of the Eastern Regional Sports Commission. The progressive wind of change in sports administration blew to the Northern Region and with the carving out of the Midwest out of the former Western Region, the Midwest Sports Council was also established in 1964 (Adelakun, 2021).

After the creation of the twelve states on May 27, 1967, various state sports Councils were established as follow:

1. Lagos State Sports Council 1967,

2. River State Sports Council 1968,

3. Kwara State Sports Council 1968,

4. Kano State Sports Council 1968,

5. North Central State Sports Council 1968,

6. Benue Plateau State Sports Council 1968,

7. South Eastern State Sports Council 1969,

8. North Eastern State Sports Council 1969,

9. North Western State Sports Council 1969.

With the creation of additional states in 1976, the old Western State was split into Ogun, Oyo and Ondo, so also the Eastern state was split into Imo and Anambra. Each of these states established her sports council. In 1991 when Abia state was carved out of the old Imo state, Abia State Sports Council was also established (Adelakun, 2021). Adesanya (1992) highlighted the duties of these sports councils as follows:

1) To assist financially or otherwise the organizing and holding of matches, competitions or contest between amateurs and to arrange, promote, organize or hold such sports, matches, competition, contests, ceremonies and functions as may, in its opinion, be necessary or desirable for the purpose of promoting sports generally.

2) To maintain playing fields and premises for the practice of or for the holding of matches, competition or contests between amateurs.

3) To assist financially or otherwise the participation of any Nigerian team of amateurs in sports held in Nigeria or elsewhere.

4) To establish and maintain sports centers for the training of persons as instructors in, or organizers of any form of sport. 
5) To assist financially or otherwise the training of Nigerians to fit them to be instructors, coaches, or organizers of any form of sport.

6) To assist financially or otherwise, any school, club, association, or other body for the purpose of encouraging participating by such school, club, association or other body in any form of sport.

7) To supervise, control, and where in the opinion of the council it is necessary so to do, take over and manage for such period as the council may think fit, the affairs and activities on any sports club, association or other body assisted financially or otherwise by the council, and ...

8) To exercise effective control over sports, matches, competitions, contests, ceremonies and functions arranged, promoted, organized or held by the council or by any sports club, association or other body assisted financially or otherwise by the council and over the participants.

All the States' sports councils operate from the state capitals and make necessary organization and administrative arrangement to do anything within the law to promote and encourage sports participation to the grass-root level of the states (Orunaboka, et al., 2015). Some states, therefore, have zonal officers stationed there in order to play the roles listed above (Deemua, et al., 2018). With these, sports councils, clubs and sporting associations emerged. Federal Republic of Nigeria (FRN, 2009) averred that, administratively, sport is administered at the state level through Sports Councils, and at the National level through the National Sports Commission.

FRN (2009) National Sports Policy, stated the roles of State Governments in sports through sports councils as follows:

1) To provide adequate and standard facilities, organise and deliver sports services at their level;

2) Encourage development of physical education and sports in schools;

3) Identify and develop talented athletes within the state;

4) Ensure that at least $5 \%$ of the total budget for sports is earmarked for maintenance of sports facilities and infrastructure;

5) Organise and hold regular competitions for all sports;

6) Collaborate with the State Ministry of Education on matter of schools' sports;

7) Adequately prepare athletes for national competitions;

8) Pay subscriptions to National Sports Federations.

Since human beings are the most important element in state sport council, there is need for managers of the state sports council to make them satisfied with their jobs. Fasan (1994) stated that workers in sport councils must have sense of belonging. They should feel that they are part of the council if they are to be satisfied with their job. He further stated that managers of sport councils must ensure that workers have sense of security. There must be assurance of job security; there must be measure of stability and also flexibility in the policies and programmes of the sports councils. And there must be coordination of interest if the council is to achieve its stated objectives (Adelakun, 2021). 


\subsection{Socio- Demographic Variables and Job Satisfaction}

Socio-demographic variables are the general characteristics of a population which include gender, age, educational qualification, religion, marital status, religion, ethnicity, location and so on. Studies have shown that some socio-demographic variables such as gender, marital status, length of service and educational qualification affect job satisfaction (Adelakun, 2021; Shrestha, 2019, Deemua, et al., 2018).

\subsection{Gender and Job Satisfaction}

Gender is one of the most important demographic factors frequently examined in job satisfaction studies. However, the results have always been contradictory (Rast \& Tourani, 2012). Several studies indicate that gender has significant effect on job satisfaction. Also, Kim (2005), Clark (1997) as well as Sloane and Williams (1996) (as cited in Rast \& Tourani, 2012) found out that women are more satisfied with their work than men. Additionally, there is no significant relationship between employees' gender and job satisfaction (Rast \& Tourani, 2012; Oshagbemi, 2000; Smith, 1998). As for Donohue and Heywood (2004) they made efforts in their study to establish a relationship between gender and job satisfaction, but they were not successful in proving that there is a connection in between job satisfaction and gender. Thus, in their concluding remark, there was no concrete evidence that gender predicts job satisfaction.

Milledzi, et al. (2018) stated that there are divergent opinions in literature indicating that females have higher level of job satisfaction while other studies indicate that male have higher level of job satisfaction. There are still other authors who found no significant difference between male and female with regards to their levels of job satisfaction. The confusion is further compounded by the report of Walker and Sorce (2009) who stated:

"Although gender has been reported to affect job satisfaction from time to time, overall, there is very little evidence to support the idea that gender directly influences job satisfaction. Contradicting survey results on this matter further confuse the theory, although it has been determined that men and women have differences in what needs are satisfied by a job, which may impact how they respond to satisfaction questions."

Gender has to do with the role or action ascribed to male or female. The issue of gender in workplaces has generated more debates in recent times. Women are increasingly getting more educated and with more certificates nowadays. Their level of employment opportunities most especially in public sector is also increasing geometrically. It should be noted that there are few, if any, important difference between men and women that will affect their job performance, job commitment and job satisfaction. There is no consistent male and female difference in motivation, sociability and drive. Robbins and Sanghi (2002) stated that "given the significant changes that have taken place in the last 35 years in terms of increasing female participation rates in the workforce and rethinking what constitutes male and female roles, one should operate on the assumption that 
there is no significant difference in job productivity and invariably job satisfaction between men and women". Although women on the average are in lower paid and lower quality employment, it is surprising that women report similar level of job satisfaction to men (Ogunbameru, 2004). The probable reason for this is that, women, in spite of having strong emotional attachment to work, women have lower expectation and therefore employ different societal assessment process than men when evaluating their jobs. Job characteristics also have different impact on both sexes. For instance, Pugliesi (as cited in Ogunbameru, 2004) stated that autonomy looks to be more important for men's job satisfaction than women's while on the other hand supportive supervision has more impact on women's job satisfaction than men's.

Although many researchers suggest that there is no significant difference in job satisfaction of men and women, however, what motivates men and women in the work environment differs. Nash (as cited in Ramayah, et al., 2001) observed that factors that influence job satisfaction differ from men to women in terms of importance of ranks. Generally, men ranked security first, followed by advancement on the job, type of work, company, pay, co-worker, supervision, benefit, duration of work and then working conditions in that order. Whereas women ranked type of work first, followed by company, job security, co-workers, advancement, supervision, pay, working condition, duration of work and benefit in that order. Spector (2012) found out that there is no significant difference based on gender in job satisfaction. However, it was explained that this might be as a result of male participants having higher positions (managerial/ professional jobs) than females who had more clerical jobs. Women could be happier when they have less demanding jobs because of their low expectations. The society in which we live expects less from women. It is believed that women only supplement whatever their husbands or men contribute in the family.

Clark (as cited in Milledzi, et al., 2018) noted the differentials in the levels of job satisfaction of males and females in Britain. Clark found out that females have higher levels of job satisfaction when compared to their male counterparts despite being in jobs with lower pay and promotion opportunities. The cross-sectional data collected and analysed by Long (cited in Milledzi, et al., 2018) equally revealed that females were more satisfied with their job than males. In contrast, the study of Castillo, et al. (2008) showed no significant difference in the levels of job satisfaction of job satisfaction of males and females. Similarly, Rentner and Bissland (as cited in Adelakun, 2021) found no significant differences in the overall job satisfaction levels of both males and females public relation workers. In state sports councils in Nigeria, can gender predict job satisfaction of sports administrators?

\subsection{Age and Job Satisfaction}

The relationship between age and job satisfaction is enmeshed in controversy. Some scholars believe that age predicts job satisfaction of workers while others believe it does not. Some researchers found out that there is a relationship between age and job satisfaction, others did not find a significant relationship between job satisfaction and age 
in their studies. Samita (2015) stated that research has shown that as employees grow older and acquire seniority, they tend to be slightly more satisfied with their job while new recruits tend to be less satisfied because of higher expectations. Ogunbameru (2004) stated that very recently, there are indications that there is a relationship between age and job satisfaction, however, the relationship is complex rather than linear because older workers do not necessarily report higher levels of job satisfaction than younger workers.

In looking at the effect of age on turnover, absenteeism, productivity and job satisfaction, Robbins and Sanghi (2005) stated that the older a worker gets, the less likely he would quit his job. This is not surprising because as a worker gets older, the job opportunities available to him are getting fewer. Moreover, older workers are less likely to resign than younger workers because their long years in service tend to provide them with higher wage rates, longer paid vacations and more attractive pension benefits. Besides, older workers would have risen in positions, which may make them content with their present conditions. Milledzi, et al., (2018) stated that the more advanced in age a worker is, the more satisfaction he would experience from his job and the less likely he would be thinking of leaving the organisation. On the issue of age and job satisfaction Robbins, et al., (2005) stated:

"On the issue of age and job satisfaction, the evidence is mixed. Most studies indicate a positive association between age and satisfaction, at least up to the age of 60. Other studies however have found a U-shaped relationship. Several explanations could clear up these results, the most plausible being that these studies are intermixing professional and nonprofessional employees. When the two types are separated, satisfaction tends to increase continually among professional as they age, whereas it falls among non-professional during middle age and then rises in later years." (p.41)

The implication of this is that, depending on the group of workers under evaluation, the relationship between job satisfaction and age could be positive or negative. As a professional grows older, his level of job satisfaction increases, whereas, it is not so with a non-professional, though in later years of a non-professional, the level of satisfaction may increase.

Walker and Sorce (2009) reported that as people climb the career ladder; their job satisfaction level is expected to increase. As the individual gains more work experience, they get closer to their preferred work situation and this increases their level of satisfaction. However, there is a caveat: survey data does not always support this view. Ogunbameru reported that in one study, eighty control variables which might cause the age effect, such as pay and prospect, were included in a sophisticated statistical analysis, but a significant age effect persisted. In other words, age itself rather than variables associated with it has a direct impact on job satisfaction. Similarly, Walker and Sorce (2009) also reported a 25-year study of 169 high-school graduates where it was found that the average job satisfaction scores remained the same during their adult years, whereas the average job congruence (measured by the similarity between the individual's major 
in college and the position held at the time of the survey) increased significantly. Davis (2004) found no evidence to support the hypothesis that older people tend to be more satisfied with their jobs than younger people. Macky (2008) stated that no statistically significant generational differences have been found for job satisfaction in recent studies. To Cano and Miller, (as cited in Milledzi, et al., 2018) age is not significantly related to job satisfaction.

Young people may report satisfaction not only because of the novelty of work but also because of the prevalent rates of youth unemployment. Ogunbameru (2004) noted that in their late 20s, expectation of work may rise and individuals compare themselves with peers who may well have found more attractive jobs. The report concluded that improved general well-being and the possibility that social comparison processes may be less important may account for the rise in job satisfaction in older workers.

Similarly, Oshagbemi (as cited in Adelakun, 2021) averred that the relationship between job satisfaction and age is uncertain. The author puts forward two explanations for that assertion: first, the curvilinear explanation and second, the linear relationship. The linear relationship is described by the idea of accommodation and an increased ability to have more rewarding jobs due to seniority and experience. The curvilinear relationship is explained by the idea that stress on the job increases over time as changes in the environment increase pressure to perform at higher levels and the desire to retire earlier, all collide. Rhodes (as cited in Milledzi, et al., 2018) stated that the relationship between job satisfaction and age can best be represented by a positive linear relationship, which he described as a weak relationship with correlations coefficients falling from 0.10 to 0.20 . Further analysis on the findings showed that the type of organisation, whether service, manufacturing or government dictates the relationship between age and job satisfaction. Therefore, age-job satisfaction relationship varied across organisations because individual parameters varied between types of organisation.

Milledzi, et al., (2018) summed up the findings of researchers on age and job satisfaction as follows:

"Researchers have attempted to establish relationships between age and the level of job satisfaction, but the findings of these studies have been inconsistent. This is because five types of relationships exist: positive linear, negative linear, U-shaped, inverted U-shaped and no significant relationship. For instance, the relationship between age and job satisfaction tends to be a $U$-shaped function where job satisfaction with younger employees is high at the initial stage, then drops with time for several years, and finally picks up again with age."

Reviewed literature in this study showed that in some studies, age as a sociodemographic variable is significantly related to overall levels of job satisfaction while in other studies age is not significantly related to job satisfaction. However, it is to be noted that other variables contribute to the relationship between age and job satisfaction (Adelakun, 2021). The authors did not look at the extent of satisfaction of different ages 
at the entry points. For instance, will workers of different ages, may be 25 years, 30 years, 35 years and 40 years who are employed the same day with the same qualification and on the same grade level and step, be equally satisfied with their work? This has not been properly highlighted in literature. Most authors focussed on age on the job and job satisfaction. However, one thing is very clear, many authors agree that age could predict job satisfaction of workers (Deemua, et al., 2018).

In the field of sport, the situation may not be different. Age may be significantly related or not related to job satisfaction. It could predict job satisfaction. Young sports administrators and coaches are always eager to prove themselves and excel in their chosen career (Adelakun, 2021). However, as the time progresses, they tend to reduce their input because of lack of novelty and new challenges, but older sports administrators and coaches tend to be more satisfied as they climb the ladder towards becoming Directors in the Ministry of sports or other important positions in sports ministry (Adelakun, 2021).

\subsection{Educational Qualification and Job Satisfaction}

Educational qualification is another important socio-demographic variable which has attracted a lot of studies from researchers. This has to do with the amount of education that a worker had received before joining an organisation or the amount of education he has received while working in an organisation. (Adelakun, 2021) This is measured in terms of certificates a worker has. It is the extent to which a worker attended formal schools and obtained a certificate from primary school to university. The worker may even have post graduate certificates like masters and doctorate degrees. Sometimes workers may have professional certificates that qualify them for the job in addition. However, Ashraf, Ahmad, Shaikh, Bhatti and Soomro (2013) stated that studies of numerous researchers presented a contradictory conclusion on educational qualification as a correlate of job satisfaction. Similarly, Oladipo, Ismi Bahama and Adekanye (2017) reported that a couple of researchers found a positive relationship between the educational qualification of employees and their level of job satisfaction, while others found a negative association between educational level and job satisfaction. While some studies showed a significant relationship between education and job satisfaction, others like Groot and Brink (cited in Ashraf, et al., 2013) identified no noteworthy impact of education on job satisfaction. Sinha (2009) stated that the majority believe there is a positive relationship between education and job satisfaction, but it is just to assume that more qualified employees will be more frustrated with allotted routine jobs. He however concluded that a few researchers concluded that higher education leads to high satisfaction. Franek and Vacera (2008) stated that in many studies, job satisfaction has been found to decrease with increasing levels of education. The author went further to state that it is assumed that education which does not lead to extrinsic rewards like money, prestige, autonomy and so on, would lead to dissatisfaction with work by producing unfulfilled expectation and aspiration. 
In Nigeria, first degree is the highest qualification mostly required at the entry point to civil service. Other qualifications are an added advantage to its holders (Adelakun, 2021). Workers with first degree at entry point are usually placed on Grade Level 8. Sometimes a worker may possess a Master's degree, such a worker will still be placed on the same grade level with a first degree holder and grow on the same job with a first degree holder without any preferential treatment except in few specialised areas (Adelakun, 2021).

\subsection{Length of Service and Job Satisfaction}

This is also known as tenure in some literature and empirical studies. It is defined as time on a particular job. Robbins, et al., (2005) stated that tenure and satisfaction are positively related. When age and length of service are treated separately, length of service appears to be a more consistent and stable predictor of job satisfaction. Tenure is also a good predictor of productivity. In a study on the effect of length of service on Job satisfaction of university teachers, Oshagbemi (2003) found that the overall job satisfaction of university teachers is significantly correlated with length of service in present university. Ronen (cited in Sarker, et al., 2003) that intrinsic satisfaction in a job adds to changes in the overall satisfaction of employees over time, where length of service is related to job satisfaction and dissatisfaction. Workers tend to adjust their work value to the condition of their workplace, thereby resulting in greater job satisfaction or workers who experience little achievement, recognition and responsibility are more prone to experience dissatisfaction and leave the organisation (Adelakun, 2021).

Going forward, Clark, et al. (as cited in Adelakun, 2021) acknowledged that workers with long length of service may experience higher job satisfaction because they got a job which matches their desire and needs or find opportunities for promotion which might lead to higher job satisfaction. However, there is a warning that longer tenure in a job may result in boredom or lower level of satisfaction. Robbins, et al. extended the impact of length of service to consequences of job dissatisfaction. The authors stated that the research relating length of service to absence is straightforward. Studies consistently demonstrate seniority to be negatively related to absenteeism. In terms of both frequency of absence and total days lost at work, tenure is the single most important explanatory variable. Sinha (2009) stated that if we look into the general understanding, we would probably say that a person who starts his career development at early stage is more enthusiastic as compared to later stages of his job, but the interesting thing to understand here is that job satisfaction picks up again when the worker is close to his retirement. The probable explanation for this is lack of alternative job opportunities for him.

\subsection{Rank (Job Level) and Job Satisfaction}

Studies investigating the relationship between rank and job satisfaction are very few. Evidence from literature suggests that there is correlation between rank and job satisfaction. Franek, et al. (2008) substantiated that rank is a reliable predictor of job satisfaction, with workers at higher ranks being generally satisfied with their jobs 
compared to workers at lower ranks. Job satisfaction increases with occupational level. Near, et al. quoted by Franek, et al. (2008) reported that the strongest predictor of job satisfaction among many other variables were occupational level, that is, rank. Also, Clark (as cited in Franek et al., 2008) examined the difference in job satisfaction between managers and regular employees and found that managers reported higher levels of job satisfaction than regular employees. Thus, rank predicted job satisfaction.

\section{Theoretical Review}

\subsection{Herzberg's Two-Factor Model}

Herzberg's two-factor model of satisfier and dissatisfier was developed by Frederick Herzberg, Mausnet and Synderman in 1957 following an investigation of accountants and engineers (Armstrong, 2004). It was assumed that people have the capacity to report accurately the conditions that made them satisfied and dissatisfied with their job (Adelakun, 2021). Ogunbameru (as cited in Adelakun, 2021) stated that Herzberg's twofactor model focuses on the effects of certain job facets on job satisfaction.

Herzberg's two-factor- theory distinguished between two categories of factors affecting people in their jobs. The first category is known as maintenance or job-context factor (Welhrich \& Koontz, 2005). Maintenance or job-context factor refers to the characteristics of the workplace. These include company policies, working conditions policies, working, pay, co-workers supervision and so on. Bateman and Snell (cited in Adelakun, 2021) explained that these factors can make people unhappy if they are poorly managed. If they are well managed and viewed as positive by employees, the employees will no longer be dissatisfied. However, no matter how good these factors are, they will not make people truly satisfied to do a good job. In explaining the maintenance or jobcontext factor, Weihrich and Koontz (2005) stated that company policy and administration, supervision, working conditions, interpersonal relations, salary, status, job security and personal life were found by Herzberg to be only dissatisfiers and not motivators. In order words, if they exist in a work environment in high quantity and quality, they yield no dissatisfaction. Their existence does not motivate in the sense of yielding satisfaction their lack of existence would however result in dissatisfaction. Dissatisfiers will not motivate people in an organization, but they must be present so that the case of dissatisfaction will not arise. The second group is known as the motivators or the satisfiers. They are all related to job contents. This is in tandem with Ogumbameru (2004) who stated that motivators' needs are associated with the actual work itself and how challenging it is. It is at this point that socio-demographic variables such as workers or employees' age, gender, educational qualification and experience i.e. length of service plays crucial role owing to the fact that when assigned job roles and responsibilities did not meet some or all of these socio-demographic factors, there is bound to be cases of dissatisfaction arising from underemployment, fatigue, burnout and so forth. Thus, Herzberg's theoretical concept of motivators encompasses factors that make a job in tandem with available capacity, more motivating and more interesting in a bid to ensure 
that the workers invest more of their aptitudes in meeting set goals and objectives of the sport organization.

Furthermore, the implication of Herzberg's two-factor model of satisfier and dissatisfier in consonant with this study is captured in the works Armstrong (2004) who stated that:

"The wants of employees are divided into two groups. One group revolves around the need to develop in one's occupations as a source of personal growth. The second group operates as an essential base to the first and it is associated with fair treatment in compensation, supervision, working conditions and administrative practices. The fulfillment of the needs of the second group does not motivate the individual to high levels of job satisfaction and to extra performance on the job. All we can expect from satisfying this second group of needs is the prevention of dissatisfaction and poor job performance." (p. 224)

Workers in the sports councils need both satisfiers and dissatisfiers in order to be satisfied with their job. Coaches, sports officers, organizing secretaries and other employees of the sport councils need congenial working environments to work with satisfaction in their respective work schedule. They need adequate job security; they need opportunity for growth and development, adequate remunerations and good working conditions (i.e. working conditions that are in tandem with their capabilities) to function effectively. If their satisfiers and dissatisfiers are met, there would be low turnover, absenteeism, low picketing and other behaviours that are attributed to lack of job satisfaction.

\subsection{Review of Related Empirical Studies}

Rintaugu (2013) examined sources of job satisfaction among sports personnel in Kenyan Universities. Forty (40) sports personnel working in 12 Kenyan Universities (public and private) were used for the study. Data were analyzed through t-test and one-way Analysis of variance (ANOVA). The instrument used for the data collection was Job Descriptive Index (JDI). The study was interested in finding out whether the level of job satisfaction of personnel in Kenyan Universities could be influenced by selected sociodemographic features of gender, age, marital status, highest academic qualifications, experience in sport administration and academic ranks. The t-test and ANOVA results of the study showed that satisfaction levels differed based on University status, status, age and highest academic qualification. University status returned significant differences on promotional opportunities, rewards and working conditions. The author found that selected socio-demographic characteristics of gender, marital status, experience in sport administration and academic rank did not return significant differences on promotional opportunities. The older sport personnel according to the study are more satisfied than the younger sports officers. Generally, the study found that sport personnel were satisfied with relationships with colleagues, co-workers, and relationships with administrators. The study is relevant to this present study because it was carried out in 
sport circles and it examined some socio-demographic variables that are under consideration in this study.

Bawa and Velnampy (2013) conducted a study on the determinants of employee satisfaction (ES) in a public health service organization (PHSO) in eastern province of Sri Lanka. Primary and secondary sources data were collected. Primary data were collected using questionnaire. 100 hospital employees were used for the study. Factor analysis and regression analysis were used for the study. Psychological and structural factors were determinants of employees' satisfaction in public health service organizations. The variables accounted for $93 \%$ of total variation for employee satisfaction. The study highlighted environmental factors (opportunity to job, work environment, working environment, social environment and participated environment) psychological factors (positive attitude, negative attitude assertiveness, agreeableness and workload) structural factors (work autonomy, job stress, supervisory, job security, self-actualization, distributive justice, promotional chances, pay and flex,- time) as good predictors of job satisfaction in public health service organization. The study is relevant to this study because it was conducted in a public organization and it examined some variables which this current study is also examining. These variables include work environment, supervision, job security, autonomy, promotion, social environment and so forth.

Onifade, et al. (2009) conducted a study on the level of job satisfaction and performance of sport officers in Lagos state secondary schools. Data were collected from 200 sports officers selected randomly from ten (10) Local Education Districts of Lagos State (144 males and 56 females). The instrument used for the study was the Job Descriptive Index (JDI). The result of the study showed that there is no significant relationship between job satisfaction and job performance $(r=0.29)$. The study also revealed that sport officers in Lagos state are generally satisfied with their job $(X=203.5)$. Supervision with the mean of $X=53.43$ was rated as highest contributor to overall job satisfaction. Job itself $(X=53.36)$; co-workers $(X=50.89)$. Pay was the least rated contributor to overall job satisfaction with a mean rating of 20.37. The result also showed a significant difference in the overall job satisfaction based on age, gender and experience, while educational qualification has no significant statistical effect on job satisfaction. The study further revealed that male sports officers were more satisfied than female sports officers $(t=50.31, p<0.05)$; older sports officers were more satisfied with their job than younger sports' officers $(t=24.94, \mathrm{p}<0.05)$ while sport officers with more years of experience on the job were more satisfied with their job than sports' officers with fewer years of experience $(t=18.75, P<0.05)$. The study further reported that sports' officers are more satisfied with facets of supervision, job itself and co-workers, while pay and promotion were rated below the first three facets of job satisfaction. The study is similar to this study on account of the fact that both studies share the same perspective that supervision, promotion, pay and demographic variables of gender, age, length of service and so on have significant effects in determining the level of job satisfaction in the sports industry. 


\section{Summary of Reviews}

The theoretical review on Herzberg's two-factor model of satisfier and dissatisfier as examined in this paper portrayed the fundamentals of examining socio-demographic variables as predictors of among sports council administrators in southern Nigeria. The model emphasized that when job roles and responsibilities of sport council employees are compatible with some socio-demographic variables, the likelihood of satisfaction among the workers is expected to be high and vice-versa. The model also reiterated that as much as satisfier is vital to be given proper consideration, so also is the dissatisfier, in ensuring a balanced approach towards the realization of job satisfaction among sport council employees. From the literature, scholars revealed that the to be metre is a good number of socio-demographic predictors of job satisfaction among sport council workers, which when integrated into the existing job policy of sport council, it will go a long way to spur the workers effort and in turn, promote excellence in affected sport council or organisation. However, empirical works were reviewed with none having complete similarity in content coverage and geographical scope with the study under investigation. This is the gap this study bridged.

\section{Methodology}

A cross-sectional survey design was adopted for this study. The study population comprised 3000 sports council administrators in the 3 subregions of southern Nigeria (Source: State Director of Sports). A sample of 450 sports council administrators representing $15 \%$ of the population was drawn using multi-stage sampling technique. The instrument titled, Socio-Demographic Predictors of Job Satisfaction (QSDPJS) was used for data collection. QSDPJS consists of forty (40) items of ten (10) sections. This was coded in a 5-point psychometric scale of Not Satisfied (NS), Slightly Satisfied (SS), Satisfied (S), Very Satisfied (VS) and Extremely Satisfied (ES) with values 1, 2, 3, 4 and 5 respectively. Face and content validities were ensured by experts including the researcher's supervisor. The reliability coefficient of the QSDPJS was calculated to be 0.86 with the help of Pearson Product Moment Correlation technique. Percentages, mean scores $(x)$, standard deviation and beta weights $(\beta)$ were used to answer research questions. Analysis of Variance (ANOVA) associated with multiple regression were used to test the null hypothesis at 0.05 alpha level. The following index showed the extent of satisfaction:

$\begin{array}{lll}1-2.49 & = & \text { Low Extent (not satisfied) } \\ 2.50-3.49= & \text { High Extent (satisfied) } \\ 3.50-5= & \text { Very High Extent (very satisfied) }\end{array}$

(Source: Adelakun, 2021). 


\section{Results}

Table 1: Socio-demographic dispersion of respondents (Sport Council Administrators) in Southern (South-south, South-east, South-west) Nigeria

\begin{tabular}{|c|c|c|c|c|c|}
\hline Variable & Value labels & $\begin{array}{l}\text { South-South } \\
\qquad(\mathrm{N}=159)\end{array}$ & $\begin{array}{c}\text { South-East } \\
(\mathbf{N}=128)\end{array}$ & $\begin{array}{l}\text { South-West } \\
(N=163)\end{array}$ & $\begin{array}{c}\text { Total } \\
\text { (Southern } \\
\text { Nigeria) }\end{array}$ \\
\hline \multirow{3}{*}{ Gender } & Male & $121(76.1 \%)$ & $65(50.8 \%)$ & $91(55.8 \%)$ & $277(61.6 \%)$ \\
\hline & Female & $38(23.9 \%)$ & $63(49.2 \%)$ & $72(44.2 \%)$ & $173(38.4 \%)$ \\
\hline & Total & 159 & 128 & 163 & 450 \\
\hline \multirow{4}{*}{ Age } & Below 30 years & $28(17.6 \%)$ & $32(25.0 \%)$ & $26(16.0 \%)$ & $86(19 \%)$ \\
\hline & $31-45$ years & $82(51.6 \%)$ & $65(50.8 \%)$ & $83(50.9 \%)$ & $230(51.1 \%)$ \\
\hline & $46-60$ years & $49(30.8 \%)$ & $31(24.2 \%)$ & $54(33.1 \%)$ & $134(29.8)$ \\
\hline & Total & 159 & 128 & 163 & 450 \\
\hline \multirow{4}{*}{$\begin{array}{l}\text { Academic } \\
\text { qualification }\end{array}$} & ND/NCE & $51(32.1 \%)$ & $51(39.8 \%)$ & $39(23.9 \%)$ & $141(31.3 \%)$ \\
\hline & HND/B.Sc./B.Ed. & $98(61.6 \%)$ & $75(58.6 \%)$ & $97(59.5 \%)$ & $270(60 \%)$ \\
\hline & M.Sc./Ph.D. & $10(6.3 \%)$ & $2(1.6 \%)$ & $27(16.6 \%)$ & $39(8.7 \%)$ \\
\hline & Total & 159 & 128 & 163 & 450 \\
\hline \multirow{4}{*}{ Length of service } & Below 10 years & $47(29.6 \%)$ & $52(40.6 \%)$ & $86(52.8 \%)$ & $185(41.1 \%)$ \\
\hline & 10-21 years & $69(43.4 \%)$ & $41(32.0 \%)$ & $41(25.2 \%)$ & $151(33.6 \%)$ \\
\hline & 21-35 years & $43(27.0 \%)$ & $35(27.3 \%)$ & $36(22.1 \%)$ & $114(25.3 \%)$ \\
\hline & Total & 159 & 128 & 163 & 450 \\
\hline \multirow{5}{*}{ Rank/Grade level } & GL 7-10 & $94(59.1 \%)$ & $82(64.1 \%)$ & $43(26.4 \%)$ & $219(41.1 \%)$ \\
\hline & GL 11-13 & $48(30.2 \%)$ & $28(21.9 \%)$ & $80(49.1 \%)$ & $156(33.6 \%)$ \\
\hline & GL $14-16$ & $17(10.7 \%)$ & $18(14.1 \%)$ & $40(24.5 \%)$ & $75(25.3 \%)$ \\
\hline & Total & 159 & 128 & 163 & 450 \\
\hline & \% by sub-region & $35.3 \%$ & $28.4 \%$ & $36.2 \%$ & \\
\hline
\end{tabular}

Table 1 showed the socio-demographic characteristics of respondents (sport council administrators) in Southern (South-south, South-east, South-west) Nigeria. A total number of $277(61.6 \%)$ respondents were males, while $173(38.4 \%)$ were females. A further breakdown shows that in the South-South, $121(76.1 \%)$ of the respondents were males while $38(23.9 \%)$ were females. In the South-East, 65(50.8\%) were males and $63(49.2 \%)$ were females. 91(55.8\%) were males and 72(44.2\%) were females in the South West. A total number of $86(19 \%)$ respondents were below the age of 30 years, 230 respondents representing $51.1 \%$ were between the age of 31 and 45 years while $134(29.8 \%)$ were between the age of 46 and 60 years.

Further analysis according to regions shows that in the South-South, 28(17.6\%) of the respondents were below the age of 30 years, 82(51.6\%) were within 31-45 years and $49(30.8 \%)$ were within 46-60 years of age. In the South-East, 32(25.0\%) were below 30 years, $65(50.8 \%)$ were $31-45$ years and $31(24.2 \%)$ were within $46-60$ years. In the SouthWest, $26(16.0 \%)$ were below 30 years, $83(50.9 \%)$ were within $31-45$ years and $54(33.1 \%)$ were within 46-60 years of age. In the southern region as a whole, 141(31.3) of the respondents hold National Diploma or Nigeria Certificate in Education; 270 of the respondents, representing 60\% hold Higher National Diploma or first degree, while 39 
$(8.7 \%)$ hold post graduate degrees. In the South-South region, 51(32.1\%) had National Diploma/Nigeria Certificate in Education (ND/NCE), 98(61.6\%) had HND/B.Sc./B.Ed. certificate and 10(6.3\%) had M.Sc./Ph.D. In the South-East, 51(39.8\%) had ND/NCE certificate, 75(58.6\%) had HND/B.Sc. /B.Ed. certificate and 2(1.6\%) had M.Sc./Ph.D. While in the South-West; 39(23.9\%) had ND/NCE certificate, 97(59.5\%) had HND/B.Sc. /B.Ed. certificate and $27(16.6 \%)$ had M.Sc./Ph.D.

In southern Nigeria as a whole, 185 respondents, representing $41 \%$ have spent below ten years in service; 151(33.6\%) of the respondents have spent between 10 and 20 years in service while 114(25.2\%) have spent between 21 and 35 years in service. A further analysis according to regions shows that $47(29.6 \%)$ of the respondents in the South-South had been in service for less than 10 years, 69(43.4\%) were in service for 10-20 years and $43(27.0 \%)$ were in service for $21-35$ years. In the South-East, $52(40.6 \%)$ had been in service for less than 10 years, 41(32.0\%) were in service for between 10-20 years and 35(27.3\%) had been in service for between 21-35 years. In the South-West, 86(52.8\%) had been in service for less than 10 years, $41(25.2 \%)$ were in service for $10-20$ years and $36(22.1 \%)$ were in service for 21-35 years.

Generally, in the southern region, $219(48.7 \%)$ of the respondents were between grade level 7 and 10; 156(34.7\%) were between grade level 11 and 13, while 75 respondents were between grade level 14 and 16. In the South-South, 94(59.1\%) were GL 7-10 officers, $48(30.2 \%)$ were GL $11-13$ officers and $17(10.7 \%)$ were between GL 14-16. In the South-East; $82(64.1 \%)$ were GL 7-10 officers, 28(21.9\%) were GL 11-13 officers and $18(14.1 \%)$ were GL $14-16$ officers. South-West; 43(26.4\%) were GL 7-10 officers, 80(49.1\%) were GL 11-13 officers and 40(24.5\%) were GL 14-16 officers

\subsection{Answer to Research Questions}

Research Question 1: To what extent are sport administrators in the sport council in southern Nigeria satisfied with their job?

Table 2: Weighted Mean value and standard deviation of responses on facets of job satisfaction of sport administrators in the sports council in Southern Nigeria as a whole

\begin{tabular}{|c|c|c|c|c|c|c|c|c|}
\hline $\mathbf{s} / \mathbf{n}$ & Supervision by my boss & 1 & 2 & 3 & 4 & 5 & $\overline{\mathbf{x}}$ & S.D \\
\hline 1 & $\begin{array}{l}\text { The technical "know-how" of my supervisor/boss in the } \\
\text { sports council }\end{array}$ & 55 & 89 & 134 & 110 & 62 & 3.08 & 1.22 \\
\hline 2 & $\begin{array}{l}\text { The competence of my supervisor in making decisions } \\
\text { in the sports council }\end{array}$ & 57 & 87 & 147 & 101 & 58 & 3.04 & 1.20 \\
\hline 3 & Intelligent supervision by my boss in the sports council & 46 & 64 & 202 & 106 & 32 & 3.03 & 1.04 \\
\hline 4 & The way my supervisor and I understand each other & 53 & 76 & 177 & 99 & 45 & 3.02 & 1.12 \\
\hline 5 & $\begin{array}{l}\text { The way my boss backs up his/her employees (with top } \\
\text { management) in the sports council }\end{array}$ & 67 & 88 & 156 & 89 & 50 & 2.93 & 1.20 \\
\hline 6 & The way my boss delegates work to others & 60 & 109 & 154 & 83 & 44 & 2.87 & 1.16 \\
\hline 7 & $\begin{array}{l}\text { They way my boss takes care of the complaints of } \\
\text { his/her subordinates }\end{array}$ & 73 & 101 & 134 & 97 & 45 & 2.87 & 1.21 \\
\hline
\end{tabular}


J. A. Adelakun, T. T. Orunaboka, G. A. Deemua

SOCIO-DEMOGRAPHIC PREDICTORS OF JOB SATISFACTION

AMONG SPORTS COUNCIL ADMINISTRATORS IN SOUTHERN NIGERIA

\begin{tabular}{|c|c|c|c|c|c|c|c|c|}
\hline 8 & $\begin{array}{l}\text { The way my boss provides help on hard problems in } \\
\text { the sports council }\end{array}$ & 74 & 102 & 143 & 91 & 40 & 2.82 & 1.19 \\
\hline \multicolumn{9}{|c|}{ Cluster mean $=2.96$} \\
\hline & The chance to work by myself & 1 & 2 & 3 & 4 & 5 & $\overline{\mathbf{x}}$ & S.D \\
\hline 9 & $\begin{array}{l}\text { The chance to work independently of other in the sport } \\
\text { council }\end{array}$ & 78 & 124 & 148 & 74 & 26 & 2.66 & 1.12 \\
\hline 10 & $\begin{array}{l}\text { The chance to do the kind of work that I do best in the } \\
\text { sports council }\end{array}$ & 86 & 128 & 144 & 67 & 25 & 2.59 & 1.12 \\
\hline 11 & The chance to make decisions on my own & 92 & 135 & 120 & 72 & 31 & 2.59 & 1.18 \\
\hline 12 & $\begin{array}{l}\text { The chance to develop new and better ways to do the } \\
\text { job in the sports council }\end{array}$ & 107 & 121 & 130 & 72 & 20 & 2.50 & 1.15 \\
\hline 13 & The freedom to use own judgment in the sports council & 111 & 137 & 126 & 49 & 27 & 2.43 & 1.15 \\
\hline \multicolumn{9}{|c|}{ Cluster mean $=2.55$} \\
\hline & Recognition I get for the work I do & 1 & 2 & 3 & 4 & 5 & $\overline{\mathbf{x}}$ & S.D \\
\hline 14 & The way I get full credit for the work I do & 80 & 126 & 128 & 83 & 33 & 2.70 & 1.17 \\
\hline 15 & The chance to "rub elbows" with important people & 101 & 99 & 151 & 64 & 35 & 2.63 & 1.20 \\
\hline 16 & The way I am noticed when I do a good job & 105 & 124 & 116 & 81 & 24 & 2.54 & 1.18 \\
\hline \multicolumn{9}{|c|}{ Cluster mean $=2.62$} \\
\hline & My co-workers & 1 & 2 & 3 & 4 & 5 & $\overline{\mathbf{x}}$ & S.D \\
\hline 17 & $\begin{array}{l}\text { The spirit of cooperation among my co-workers in the } \\
\text { sports council }\end{array}$ & 79 & 142 & 133 & 61 & 35 & 2.62 & 1.15 \\
\hline 18 & $\begin{array}{l}\text { The chance to develop close relationships with my co- } \\
\text { workers in the sports council }\end{array}$ & 99 & 125 & 139 & 58 & $29^{\prime}$ & 2.54 & 1.16 \\
\hline 19 & $\begin{array}{l}\text { The way my co-workers get along with each other in } \\
\text { the sports councils }\end{array}$ & 111 & 134 & 131 & 48 & 26 & 2.43 & 1.14 \\
\hline \multicolumn{9}{|c|}{ Cluster mean $=2.53$} \\
\hline & Regular promotions & 1 & 2 & 3 & 4 & 5 & $\overline{\mathbf{x}}$ & S.D \\
\hline 20 & The opportunities for advancement on his job & 75 & 177 & 120 & 58 & 20 & 2.49 & 1.05 \\
\hline 21 & The way promotions are given out on the job & 81 & 173 & 125 & 44 & 27 & 2.47 & 1.08 \\
\hline 22 & My chances for advancement on the job & 105 & 144 & 129 & 60 & 12 & 2.40 & 1.07 \\
\hline \multicolumn{9}{|c|}{ Cluster mean $=2.45$} \\
\hline & Job security & 1 & 2 & 3 & 4 & 5 & $\overline{\mathbf{x}}$ & S.D \\
\hline 23 & The way my job provides for a secure future & 76 & 129 & 167 & 41 & 37 & 2.63 & 1.12 \\
\hline 24 & The way my job provides for steady employment & 80 & 117 & 186 & 26 & 41 & 2.62 & 1.12 \\
\hline 25 & The way layoffs and transfers are provided in my job & 65 & 146 & 172 & 34 & 33 & 2.61 & 1.06 \\
\hline \multicolumn{9}{|c|}{ Cluster mean $=2.62$} \\
\hline & Pay (salary) for the work I do & 1 & 2 & 3 & 4 & 5 & $\overline{\mathbf{x}}$ & S.D \\
\hline 26 & $\begin{array}{l}\text { How my pay compares with that of similar jobs in other } \\
\text { sport organization }\end{array}$ & 142 & 145 & 136 & 16 & 11 & 2.13 & 0.98 \\
\hline 27 & Adequacy of my pay to my normal expenses & 144 & 165 & 114 & 16 & 11 & 2.08 & 0.97 \\
\hline 28 & How my pay compares with that of other workers & 162 & 131 & 130 & 15 & 12 & 2.08 & 1.01 \\
\hline
\end{tabular}


AMONG SPORTS COUNCIL ADMINISTRATORS IN SOUTHERN NIGERIA

\begin{tabular}{|c|c|c|c|c|c|c|c|c|}
\hline & The welfare packages of workers in the sport council & 1 & 2 & 3 & 4 & 5 & $\overline{\mathbf{x}}$ & S.D \\
\hline 29 & $\begin{array}{l}\text { Payment of traveling allowances when out on official } \\
\text { duty }\end{array}$ & 148 & 167 & 98 & 25 & 12 & 2.08 & 1.00 \\
\hline 30 & Payment of leave allowance in the sports council & 162 & 128 & 134 & 14 & 12 & 2.08 & 1.01 \\
\hline 31 & Pension of leave allowance in the sports council & 171 & 135 & 117 & 14 & 13 & 2.03 & 1.01 \\
\hline 32 & Health care services in the sport council & 163 & 167 & 84 & 22 & 14 & 2.02 & 1.01 \\
\hline 33 & Comfort attached to my office, like official car & 205 & 130 & 93 & 11 & 11 & 1.87 & 0.98 \\
\hline \multicolumn{9}{|c|}{ Cluster mean $=2.02$} \\
\hline & Distance of my workplace to my house & 1 & 2 & 3 & 4 & 5 & $\overline{\mathbf{x}}$ & S.D \\
\hline 34 & The amount spent on transportation to work each day & 91 & 164 & 134 & 44 & 17 & 2.40 & 1.03 \\
\hline 35 & $\begin{array}{l}\text { Easy access to my workplace and back to my house } \\
\text { from work }\end{array}$ & 101 & 153 & 135 & 42 & 19 & 2.39 & 1.06 \\
\hline 36 & Vehicle traffic from my house to my workplace & 101 & 164 & 134 & 34 & 17 & 2.34 & 1.03 \\
\hline \multicolumn{9}{|c|}{ Cluster mean $=2.38$} \\
\hline & The physical working environment of the job & 1 & 2 & 3 & 4 & 5 & $\overline{\mathbf{x}}$ & S.D \\
\hline 37 & My work routine in the sports council & 59 & 140 & 204 & 32 & 15 & 2.56 & 0.92 \\
\hline 38 & $\begin{array}{l}\text { The physical structure in the working environment in } \\
\text { the sport council }\end{array}$ & 97 & 165 & 150 & 25 & 1 & 2.32 & 0.97 \\
\hline 39 & $\begin{array}{l}\text { The pleasantness of the working environment (toilet, } \\
\text { drainage, buildings etc.) in the sports council }\end{array}$ & 120 & 157 & 135 & 23 & 15 & 2.24 & 1.01 \\
\hline 40 & $\begin{array}{l}\text { The working conditions (lighting, ventilation, air } \\
\text { condition, office space etc.) in my office. }\end{array}$ & 116 & 162 & 139 & 18 & 15 & 2.23 & 0.99 \\
\hline 41 & $\begin{array}{l}\text { The physical surroundings where I work (land scape, } \\
\text { painting of the building, noise and so on). }\end{array}$ & 122 & 176 & 117 & 22 & 13 & 2.17 & 0.98 \\
\hline
\end{tabular}

Key: 1 = Not satisfied, 2 = Slightly satisfied, 3 = Satisfied, $4=$ Very satisfied and $5=$ Extremely satisfied

Table 2 showed the job satisfaction of sport administrators in the sports council in Southern Nigeria as a whole. The table shows that 'supervision' has a weighted mean of 2.96. However, "the technical "know-how" of my supervisor/boss" $(\bar{x}=3.08)$ ranked highest by the mean score rating and was followed in succession by "The competence of my supervisor in making decisions" $(\bar{x}=3.04)$, "Intelligent supervision by my boss" $(\bar{x}$ =3.03), "The way my supervisor and I understand each other" $(\bar{x}=3.02)$, "The way my boss backs up his/her employees (with top management)" $(\bar{x}=2.93)$, "The way my boss delegates work to others" $(\bar{x}=2.87)$, "The way my boss takes care of the complaints of his/her employees" $(\bar{x}=2.87)$ and lastly "The way my boss provides help on hard problems" $\left.^{\prime \prime}=2.82\right)$ respectively. With an overall mean of $(\bar{x}=2.96)$, sport administrators in the sports councils in southern Nigeria are satisfied with supervision to a high extent.

'Autonomy', also classified as the chance to work for myself, has a weighted average of 2.55. "The chance to work independently of other" $(\bar{x}=2.66)$ ranked highest under this facet of job satisfaction by the mean score rating and was followed in 
succession by "The chance to do the kind of work that I do best" $(\bar{x}=2.59)$, "The chance to make decisions on my own" $(\bar{x}=2.59)$, "The chance to develop new and better ways to do the job" $(\bar{x}=2.50)$ and lastly "The freedom to use own judgment" $(\bar{x}=2.43)$ respectively. With a cluster mean $\left.{ }^{(\bar{x}}\right)$ of 2.55 , sports administrators in the sports council in southern Nigeria are satisfied with 'autonomy' as a facet of job satisfaction to a high extent.

Recognition I get for the work I do has a weighted mean of 2.62. "The way I get full credit for the work I do" $(\bar{x}=2.70)$ ranked highest by the mean score rating and was followed in succession by "The chance to "rub elbows" with important people" $(\bar{x}=2.63)$ and lastly "The way I am noticed when I do a good job" $(\bar{x}=2.54)$ respectively. With a cluster mean of $(\bar{x}=2.62)$, sports administrators in the sports councils in southern Nigeria are satisfied with 'Recognition' to a high extent.

Friendliness of my co-workers has a weighted mean of 2.53. "The spirit of cooperation among my co-worker" $(\bar{x}=2.62)$ ranked highest by the mean score rating "The chance to develop close relationships with my co-workers" $(\bar{x}=2.54)$ and lastly "The way my co-workers get along with each other" $(\bar{x}=2.43)$ respectively. The overall mean of $(\bar{x}=2.53)$ indicates that sports administrators in the sports council in southern Nigeria are satisfied with their relationship with their co-workers to a high extent.

Promotion has a weighted mean of 2.45. "The opportunities for advancement on his job" $(\bar{x}=2.49)$ ranked highest by the mean score rating and was followed in succession by "The way promotions are given out on the job" $(\bar{x}=2.47)$ and lastly "My chances for advancement on the job" $(\bar{x}=2.40)$ respectively. With a Cluster mean of $(\bar{x}=2.45)$, sport administrators in the sports council in southern Nigeria are satisfied with 'Promotion' in the sports council to a low extent (Not satisfied).

Job security has a weighted mean of 2.62. "The way my job provides for a secure future" $=2.63$ ) ranked highest by the mean score rating and was followed in succession by "The way my job provides for steady employment" $(\bar{x}=2.62)$ and lastly "The way layoffs and transfers are avoided in my job" $(\bar{x}=2.61)$ respectively. With an overall mean of $(\bar{x}=2.62)$, sport administrators in the sports council in southern Nigeria are satisfied with 'Job Security to a high extent.

The amount of pay for the work I do has a weighted mean of 2.10. "How my pay compares with that of similar jobs in other sport organization" $(\bar{x}=2.13)$ ranked highest by the mean score rating and was followed in succession by "Adequacy of my pay to my normal expenses" $(\bar{x}=2.08)$ and lastly "How my pay compares with that of other workers" $^{\prime}(\bar{x}=2.08)$ respectively. With the cluster mean $\left.{ }^{(\bar{x}}\right)$ of 2.10 , sport council administrators in southern Nigeria are satisfied with their pay (salary) to a low extent (Not Satisfied). 
The welfare packages of workers in the sport council has a weighted mean $\left.{ }^{(\bar{x}}\right)$ of 2.02. "Payment of traveling allowances when out on official duty" $(\bar{x}=2.08)$ ranked highest by the mean score rating and was followed in succession by "Payment of leave allowance in the sports council" $(\bar{x}=2.08)$, "Pension scheme for workers in the sports council" $(\bar{x}=2.03)$, "Health care services in the sport council" $(\bar{x}=2.02)$ and lastly "Comfort attached to my office, like official $\operatorname{car}^{\prime \prime}(\bar{x}=1.87)$ respectively. With a cluster mean $\left.{ }^{(\bar{x}}\right)$ of 2.02, sport council administrators in southern Nigeria are satisfied with welfare packages to a low extent (Not Satisfied).

Distance of my workplace to my place has a weighted mean $\left.{ }^{(\bar{x}}\right)$ of 2.38. "The amount spent on transportation to work each day" $(\bar{x}=2.40)$ ranked highest by the mean score rating and was followed in succession by "Easy access to my workplace and back to my house from work" $(\bar{x}=2.39)$ and lastly "Vehicle traffic from my house to my workplace" $(\bar{x}=2.34)$ respectively. With an overall mean of 2.38 , sport council administrators in southern Nigeria are satisfied with the distance from their workplace to their houses to a low extent (Not Satisfied).

The physical working environment in my office has a weighted mean $\left.{ }^{(\bar{x}}\right)$ of 2.30 . "My work routine" $(\bar{x}=2.56)$ ranked highest by the mean score rating and was followed in succession by "The physical structure of working environment in the sport council" ( $\bar{x}$ =2.32), "The pleasantness of the working environment (toilet, drainage, buildings etc.)" $(\bar{x}=2.24)$, "The physical working conditions of the job" $(\bar{x}=2.23)$ and lastly "The physical surroundings where I work" $(\bar{x}=2.17)$ respectively. With a cluster mean of 2.30 , sport council administrators in southern Nigeria are satisfied with their work environment to a low extent (Not Satisfied).

Research Question 2: To what extent do the socio-demographic variables of gender, age, educational qualification, length of service and rank independently predict job satisfaction of sport administrators in the sports council in southern Nigeria?

Table 3 revealed the relative contribution of the five independent variables to the dependent variable when taken independently, expressed as beta weights, viz: Age $(\beta=$ .159, $\mathrm{p}>.05)$, Gender $(\beta=-.076, p=.05)$, Academic qualification $(\beta=.010, p=.05)$, Length of service $(\beta=.186, p>.05)$ and $\operatorname{Rank}(\beta=.215, \mathrm{p}<.05)$ respectively. Hence, it could be deduced that when age, gender, academic qualification, length of service and rank were taken independently, only age, length of service and rank/grade level were significant, and this means that they could independently and significantly predict job satisfaction of sport administrators in sport council in the study. 
Table 3: Summary of beta weights $(\beta)$ analysis showing relative independent prediction of age, gender, educational qualification, length of service and rank on job satisfaction of sport administrators in sport council in Southern Nigeria

\begin{tabular}{|c|c|c|c|c|c|}
\hline \multirow[t]{2}{*}{ Model } & \multicolumn{2}{|c|}{$\begin{array}{c}\text { Unstandardized } \\
\text { Coefficient }\end{array}$} & \multirow{2}{*}{$\begin{array}{c}\begin{array}{c}\text { Standardized } \\
\text { Coefficient }\end{array} \\
\text { Beta } \\
\text { Contribution }\end{array}$} & \multirow[b]{2}{*}{$\mathbf{t}$} & \multirow[b]{2}{*}{ Sig. } \\
\hline & B & Std. Error & & & \\
\hline $\begin{array}{l}\text { (Constant) } \\
\text { Age }\end{array}$ & $\begin{array}{c}83.381 \\
.388\end{array}$ & $\begin{array}{c}4.707 \\
.113\end{array}$ & .159 & $\begin{array}{c}17.715 \\
3.419\end{array}$ & $\begin{array}{l}.000 \\
.001\end{array}$ \\
\hline $\begin{array}{l}\text { (Constant) } \\
\text { Gender }\end{array}$ & $\begin{array}{c}103.797 \\
-3.393 \\
\end{array}$ & $\begin{array}{l}3.081 \\
2.099 \\
\end{array}$ & -.076 & $\begin{array}{l}33.692 \\
-1.616 .\end{array}$ & $\begin{array}{l}.000 \\
.107 \\
\end{array}$ \\
\hline $\begin{array}{l}\text { (Constant) } \\
\text { Academic Qualification }\end{array}$ & $\begin{array}{c}98.453 \\
.365 \\
\end{array}$ & $\begin{array}{l}.242 \\
1.735 \\
\end{array}$ & .010 & $\begin{array}{c}30.367 \\
.210\end{array}$ & $\begin{array}{l}.000 \\
.834 \\
\end{array}$ \\
\hline $\begin{array}{l}\text { (Constant) } \\
\text { Length of Service }\end{array}$ & $\begin{array}{c}91.239 \\
.510\end{array}$ & $\begin{array}{c}2.201 \\
.127\end{array}$ & .186 & $\begin{array}{c}41.448 \\
4.015\end{array}$ & $\begin{array}{l}.000 \\
.000\end{array}$ \\
\hline $\begin{array}{l}\text { (Constant) } \\
\text { Rank/Grade Level }\end{array}$ & $\begin{array}{c}88.533 \\
6.290\end{array}$ & $\begin{array}{c}2.4755 \\
1.348\end{array}$ & .215 & $\begin{array}{c}35.770 \\
4.668\end{array}$ & $\begin{array}{l}.000 \\
.000\end{array}$ \\
\hline
\end{tabular}

\subsection{Test of Hypotheses}

Hypothesis 1: Socio-demographic variables of age, gender, educational qualification, length of service and rank, independently will not significantly predict job satisfaction of sport administrators in sport council in southern Nigeria.

Table 4: Summary of regression analysis showing relative independent prediction of age, gender, educational qualification, length of service and rank on job satisfaction of sport administrators in sport council in southern Nigeria

\begin{tabular}{|c|c|c|c|c|c|}
\hline Predictors & $\mathbf{R}$ & R Square & $\begin{array}{c}\text { Adjusted R } \\
\text { Square }\end{array}$ & $\begin{array}{c}\text { Std, Error of the } \\
\text { Estimate }\end{array}$ & \\
\hline Age & .159 & .025 & .023 & 21.4499 & \\
\hline Gender & .076 & .006 & .004 & 21.6650 & \\
\hline Academic Qualification & .010 & .000 & -.002 & 21.7270 & \\
\hline Length of Service & .186 & .035 & .033 & 21.3473 & \\
\hline Rank & .215 & .046 & .044 & 21.2183 & \\
\hline \multicolumn{6}{|l|}{ ANOVA } \\
\hline Model & Sum of Squares & Df & Mean Squares & $\mathbf{F}$ & Sig \\
\hline $\begin{array}{l}\text { (Age) } \\
\text { Regression } \\
\text { Residual } \\
\text { Total }\end{array}$ & $\begin{array}{c}5379.738 \\
206124.76 \\
211504.50 \\
\end{array}$ & $\begin{array}{c}1 \\
448 \\
449 \\
\end{array}$ & $\begin{array}{c}5379.738 \\
460.100\end{array}$ & 11.693 & .001 \\
\hline $\begin{array}{l}\text { (Gender) } \\
\text { Regression } \\
\text { Residual } \\
\text { Total } \\
\end{array}$ & $\begin{array}{c}1225.808 \\
210278.69 \\
211504.50 \\
\end{array}$ & $\begin{array}{c}1 \\
448 \\
449 \\
\end{array}$ & $\begin{array}{l}1225.808 \\
469.372\end{array}$ & 2.612 & .107 \\
\hline $\begin{array}{l}\text { (Academic Qualification) } \\
\text { Regression } \\
\text { Residual } \\
\text { Total }\end{array}$ & $\begin{array}{c}20.856 \\
211483.64 \\
211504.50 \\
\end{array}$ & $\begin{array}{c}1 \\
448 \\
449 \\
\end{array}$ & $\begin{array}{c}20.856 \\
472.062\end{array}$ & .044 & .834 \\
\hline $\begin{array}{l}\text { (Length of service) } \\
\text { Regression } \\
\text { Residual } \\
\text { Total }\end{array}$ & $\begin{array}{c}7347.785 \\
204156.71 \\
211504.50\end{array}$ & $\begin{array}{c}1 \\
448 \\
449\end{array}$ & $\begin{array}{c}7347.785 \\
455.707\end{array}$ & 16.124 & .000 \\
\hline
\end{tabular}




\begin{tabular}{|l|c|c|c|c|c|}
\hline \hline (Rank/Grade Level) & & & & 21.786 & .000 \\
Regression & 9808.520 & 1 & 9808.520 & & \\
Residual & 201695.98 & 448 & 450.214 & & \\
Total & 211504.50 & 449 & & & \\
\hline
\end{tabular}

Table 4 showed the independent prediction of age, gender, educational qualification, length of service and rank on job satisfaction of sport administrators in sport council in southern Nigeria. The table shows the contributions of each variable when taken independently. Age independently accounted for 2.5 per cent of the total variation, $\mathrm{R}^{2}=$ $.025, \mathrm{Adj}, \mathrm{R}^{2}=.023,\left(\mathrm{~F}_{1,448}=11.693\right) \mathrm{P}(.001)<.05$. Age is significant. Gender independently accounted for 0.6 per cent in the variation, $\mathrm{R}^{2}=.006$. Adj. $\mathrm{R}^{2}=.004,\left(\mathrm{~F}_{1,448}=2.612\right) \mathrm{P}(.107)$ $<.05$. Academic qualification independently has $\mathrm{R}^{2}=.000$, Adj. $\mathrm{R}^{2}=-.002,\left(\mathrm{~F}_{1,448}=.044\right)$ $\mathrm{P}(.834)<.05$. Length of service independently accounted for 3.5 per cent of the total variation, $\mathrm{R}^{2}=.035, \mathrm{Adj}, \mathrm{R}^{2}=.033,\left(\mathrm{~F}_{1}, 448=16.124\right), \mathrm{P}(.000)<.05$. Rank/Grade Level independently accounted for 4.6 per cent of the total variation, $R^{2}=.046, \mathrm{Adj}, \mathrm{R}^{2}=.044$, $\left(\mathrm{F}_{1,448}=21.786\right) \mathrm{P}(.000)<.05$. Independently, Age, Length of service and Rank/Grade level are significant, while academic qualification and gender are not significant when treated independently

\section{Summary of Findings}

The findings of this study are summarized as shown below:

1) Sport administrators in sport councils in southern Nigeria are satisfied by $40 \%$.

2) Socio-demographic variable of gender predicts job satisfaction of sport administrators in the sports councils in southern Nigeria by $60.9 \%$,

3) Socio-demographic variable of age predicts job satisfaction of sport administrators in the sports councils in southern Nigeria by $0.26 \%$.

4) Socio-demographic variable of educational qualification predicts job satisfaction of sport administrators in the sports councils in southern Nigeria by $5 \%$.

5) Socio-demographic variable of length of service predicts job satisfaction of sport administrators in the sports councils in southern Nigeria by $63.6 \%$.

6) Socio-demographic variables of rank (job level) independently predict job satisfaction of sport administrators in the sports councils in southern Nigeria by $66.5 \%$.

7) Independently, age significantly predicts job satisfaction of sport administrators in the sports councils in southern Nigeria.

8) Independently, length of service significantly predicts job satisfaction of sport administrators in sport councils in southern Nigeria.

9) Independently, rank (job level) significantly predicts job satisfaction of sport administrators in sports councils in southern Nigeria.

\subsection{Discussion of Findings}

The findings of this study are discussed under the following subheadings: 


\subsubsection{Extent of Job Satisfaction of Sport Administrators in the sports council in Southern Nigeria}

It was found that sport administrators in the sports councils in southern Nigeria have job satisfaction of $40 \%$. The below average extent of job satisfaction can be attributed to pay below expectation, inconsistent promotions, inadequate welfare packages, proximity of house to place of work and a work environment that falls below standard. This implies that the extent of anomalies in their job exceed what is perceived as normal in the sports councils in saner climes. The finding of this study is in tandem with Franek and Vecera (as cited in Adelakun, 2021) who found out that employees are more satisfied with their co-workers, nature of work, communication and supervision but they are less satisfied with pay, promotion, fringe benefits, contingent rewards and working conditions. The study also aligned with the findings of Rintaugu (2013) who found out that sports personnel in Kenyan universities are satisfied with supervision, relationship with colleagues/co-workers, but they are not satisfied with pay and promotional opportunities. The findings of this study reinforce the criticisms of Abraham Maslow's theory that human needs are arranged in hierarchical order and that when the lower needs are satisfied, an individual moves to the next higher order of needs.

\subsubsection{Extent at which Socio Demographic Variables of Gender, Age, Educational Qualification, Length of Service and Rank Independently Predict Job Satisfaction}

The finding showed that five socio-demographic variables (gender, age, educational qualification, length of service and rank) were independently tested, however only three out of the five (age, length of service and rank) significantly predict job satisfaction of the sport administrators. With beta weights analyses of $(\beta=.159, \mathrm{p}>.05)$ for age, Gender $(\beta=$ -.076, $\mathrm{p}=.05)$, educational qualification $(\beta=-.010, \mathrm{p}=.05)$, Length of service $(\beta=.186, \mathrm{p}>.05)$ and $\operatorname{Rank}(\beta=.215, \mathrm{p}<.05)$ respectively, it shows that independently, age, rank and length of service are good predictors of job satisfaction of sport administrators in the sports council in southern Nigeria.

This study concurs with Ogunbameru (2004) who averred that there is a relationship between age and job satisfaction. Robbins, et al. (2005) stated that age has correlation with job satisfaction. although this study did not look at the age range that is likely to be more satisfied with their jobs, the study of Robbins and Sanghi (2005) revealed that the older a worker gets, the less likely he would quit his job because the longer year they have spent in an organisation would have provided them with higher pay, longer vacations and attractive pension benefits. However, this does not connote job satisfaction. On the contrary, Ogunbameru (2004) stated that the relationship between job satisfaction and age is complex rather than linear because older workers do not necessarily report higher levels of job satisfaction than younger workers. The result of this study is also at variance with the findings of Macky (2008) and Davis (2004). Both researchers found out that age cannot significantly predict job satisfaction. More so, Robbins and Sanghi (2005) acknowledged that length of service is a good predictor of job satisfaction, which of course, corroborate the findings of this study. The authors stated that tenure and job 
satisfaction are positively related, and when age and tenure are treated separately length of service appears to be a more consistent and stable predictor of job satisfaction. The findings of this study also corroborate the findings of Franek, et al. (2008) who stated that rank is a reliable predictor of job satisfaction, with workers at higher ranks being generally satisfied with their jobs compared to workers at lower ranks. Although this study did not look at groups that are more satisfied within the ranks or grade level, it can however be deduced from the responses and/or complaints of sports administrators on irregular promotions in the sports council. The implication of their responses is that they want to grow to higher ranks perhaps because of better salary and other incentives which are attached to higher ranks.

Additionally, in a separate study carried out by Rast and Tourani (2012) as well as Kim (2005), it was discovered from both studies that gender predicts job satisfaction and that women are more satisfied with their work, which is contrary to the findings of this study. However, the result of this study is consistent with the findings of Oshagbemi (as cited in Adelakun, 2021) Groot and Brink (as cited in Ashraf, et al., 2013) and Spector (2012) who found that gender and educational qualification are not good predictors of job satisfaction.

\section{Conclusion}

Based on the findings of this study, it can be concluded that sports administrators in the sports councils in southern Nigeria are not satisfied with their job. They are not satisfied with the welfare packages in the sports council. Their salary is below expectation, their promotion is irregular and their work environments are not conducive. This could account for the poor performance of southern states in various national sports competitions in the country. Thus, the researchers have successfully analyzed sociodemographic predictors of job satisfaction among sports council administrators in southern Nigeria. This study will facilitate future works which aim at evaluating and measuring other vital predictors of sports administrators in their place of employment.

\subsection{Recommendations}

The following recommendations were made based on the findings of this study:

1) State governments in the southern sub-regions of Nigeria should make prompt payment of sports council workers at the end of the month a priority and sport administrators' salary, welfare packages and other emoluments should be enhanced.

2) Sport administrators' promotion should be properly regulated.

3) Sports administrators and other workers in sports councils should strive to get along with one another and develop close relationships that will promote a peaceful atmosphere in the sports council. 


\section{Contributions to Knowledge}

The study has been able to make the following contributions to knowledge.

1) This study has provided empirical information that the majority of sports administrators in the sports councils in southern Nigeria are not satisfied with their job. Only forty per cent (40\%) of sports administrators in the sports councils in southern Nigeria are satisfied with their job. The rest sixty per cent $(60 \%)$ are not satisfied with their job. This could account for the reason why development of sport at state level is generally not encouraging or impressive.

2) The study has also provided first-hand information that sports administrators in the sports councils in southern Nigeria are satisfied with supervision, autonomy, congenial atmosphere with co-workers, recognition they receive in the sports councils and their job security as well.

\section{Conflict of Interest Statement}

The authors declared no potential conflicts of interest with respect to the research, authorship, and/or publication of this article.

\section{About the Authors}

Adelakun, Jude Adeyemi Kayode is a PhD candidate of Sport Management in the Department of Human Kinetics and Health Education, Faculty of Education, University of Port Harcourt, Rivers State, Nigeria.

Professor Orunaboka, Tammy Tamunobelema is a Professor of Sport Administration and Marketing in the Department of Human Kinetics and Health Education, Faculty of Education, University of Port Harcourt, Rivers State, Nigeria.

Deemua Gbenegbara Amos is a senior lecturer of Sport Administration and Marketing in the Department of Human Kinetics and Health Education, Faculty of Education, University of Port Harcourt, Rivers State, Nigeria.

\section{References}

Adelakun, J. A. (2021). Socio-demographic and administrative predictors of job satisfaction among sports council administrators in southern Nigeria. (Doctoral thesis, university of Port Harcourt).

Armstrong, M. (2004). A handbook of human resource management practice. Kogan page.

Ashraf, M., Ahmad, N. Shaikh, O. A. \& Soomro, A. H. (2013). The determinants of job satisfaction in public service organisation. European Scientific journal, 9(35) 362-375.

Bawa, M. I. M. \& Velnampy, T. (2013). Determinants of employee satisfaction in public health organisation in eastern province of Sri Lanka: a pilot study. European Journal of Business management, 5(21), 62-70.

Clark, A. E. (1997). Job satisfaction and gender: why are women so happy at work? Labour Economics, 4(4), 341-372. 
Davis, G. (2004). Job satisfaction survey among employees in small businesses. Journal of Small Business and Enterprise Development, 11(4), 495.

Deemua, G. A. \& Alaubi, S. C. (2018). Influence of sports administrators' demographic variables on the achievement of sustainable grassroots sports development in Abia north senatorial zone of Abia state. International Journal of Academic Research and Reflection, 6(5), 43-50.

Deemua, G. A. (2020). Managing male and female athletes for increased sports performance in public universities in Rivers State. Advances in Social Sciences Research Journal, 7(6), 633-640.

Ekpo G. U. A. (2016). Determinants of sports development in NUGA. Educational Journal of Multi-Disciplinary Studies, 176-184.

Elendu, I. C. (2013). Sports tourism as an instrument for Nigeria's development in the 21st century: challenges and way forward. Journal of Education and Practice, 4(4), 143148 .

Fasan, O. (1994). Introduction to sport management. Beulah

Federal Republic of Nigeria. (2009). National sport policy. FRN

Franek, M. \& Vecera, J. (2008). Personal Characteristics and Job satisfaction. Ekonomical Management 4 (2) 63-75

Kim, S. (2005). Gender differences in the job satisfaction of public employees: a case study of Seoul metropolitan government, Korea. Sex Roles, 52(9), 667-681.

Macky, K., Forsyth, S. \& Boxall, P. (2008). Generational differences at work: the impact of cohort on work attitudes and outcomes. A monograph

Martins, H., \& Proenca, T. (2012). Minnesota satisfaction questionnaire - psychometric properties and validat $g$, nbion in a population of Portuguese hospital workers. FEP working papers.

Milledzi, E. Y., Amponsah, M. O. \& Asamani, L. (2018). Impact of socio-demographic factors on job satisfaction among academic staff of universities in Ghana. International Journal of Research Studies in Education, 7(2), 67-88.

Ogunbameru, O. (2004). Organisation dynamics. Spectrum.

Oladipo, K. S, Ismi, A. B. I., Bahaman, A. S., \& Adekanye, T. B. (2017). Influence of demographic variables on job satisfaction among academicians in public universities. International Journal of Innovative Business Strategies, 3(1), 127-135.

Onifade, A., Kehinde, I., \& Kehinde, E. (2009). Levels of job satisfaction and performance of sports officers in Lagos state secondary school. Journal of ICHPERSD 4(1), 70-73.

Orunaboka, T. T. (1998) Evaluation of sports program, implementation and achievement of River state at national sports festival. (Doctoral thesis, university of Ibadan).

Orunaboka, T. T., \& Ogulu, C. B. (2015). The impact of administration and sports programme implementation on the achievement of sports council at the 17th national sports Festival competition: a case study of rivers state sports council. Journal of Physical Education and Sport Management, 6(5), 32-37.

Oshagbemi, T. (2003). Personal correlates of job satisfaction: empirical evidence from UK universities. International Journal of Social Economics, 30(12), 1210-1232. 
Ramayah, T. Jantan, M., \& Tadisina, S. K. (2001). Job satisfaction: empirical evidence for alternatives to JDI. https://www.ramayah.com/journal articles/pdf

Rast, S. \& Tourani, A. (2012). Evaluation of employees' job satisfaction and role of gender difference: an empirical study at airline industry in Iran. International Journal of Business and Social Science, 3(7)91-100.

Rintaugu, E. G. (2013). Sources of job satisfaction among sports personnel in Kenyan universities. International journal of sports science. 3(6) 211-216.

Robbins, S. P. \& Sanghi, S. (2005). Organizational behavior. Pearson Education.

Samita, S. (2015). Comparison of employee satisfaction along age and gender: study of public and private sector. Journal of Business and Management, 17(8), 44-52.

Sarker, S. J., Crossman, A., Chinmeteepituck, P. (2003). The relationships of age and length of service with job satisfaction: an examination of hotel employees in Thailand. Journal of Managerial Psychology 18(7), 745-758.

Shrestha, I. (2019). Influence of demographic factors on job satisfaction of university faculties in Nepal. NCC Journal, 4(1), 59-67.

Sinha, K. (2009). Theoretical concept and theories of job satisfaction. Retrieved from https://www.shodganga.inflibnet.ac.in/bitstream/10603

Spector, P. E. (2012). Industrial and organisational psychology: research and practice. $\left(6^{\text {th }}\right.$ ed) John Wiley \&sons.

Walker, A. \& Sorce, P. A. (2009). Correlates of job satisfaction of early employee in printing and publishing occupations. Printing Industry Centre.

Weihrich, H. \& Koontz, H. (2005) Management: a global perspective. Tata McGraw Hill. 
Authors will retain the copyright of their published articles agreeing that a Creative Commons Attribution 4.0 International License (CC BY 4.0) terms will be applied to their work. Under the terms of this license, no permission is required from the author(s) or publisher for members of the community to copy, distribute, transmit or adapt the article content, providing a proper, prominent and unambiguous attribution to the authors in a manner that makes clear that the materials are being reused under permission of a Creative Commons License. Views, opinions and conclusions expressed in this research article are views, opinions and conclusions of the author(s). Open Access Publishing Group and European Journal of Physical Education and Sport Science shall not be responsible or answerable for any loss, damage or liability caused in relation to/arising out of conflict of interests, copyright violations and inappropriate or inaccurate use of any kind content related or integrated on the research work. All the published works are meeting the Open Access Publishing requirements and can be freely accessed, shared, modified, distributed and used in educational, commercial and non-commercial purposes under a Creative Commons attribution 4.0 International License (CC BY 4.0). 